\title{
Seafood safety and quality: an analysis of the supply chain in the Sultanate of Oman
}

Article

Accepted Version

Al-Busaidi, M. A., Jukes, D. J. and Bose, S. (2016) Seafood safety and quality: an analysis of the supply chain in the Sultanate of Oman. Food Control, 59. pp. 651-662. ISSN 0956-7135 doi: https://doi.org/10.1016/j.foodcont.2015.06.023 Available at https://centaur.reading.ac.uk/40573/

It is advisable to refer to the publisher's version if you intend to cite from the work. See Guidance on citing.

To link to this article DOI: http://dx.doi.org/10.1016/j.foodcont.2015.06.023

Publisher: Elsevier

All outputs in CentAUR are protected by Intellectual Property Rights law, including copyright law. Copyright and IPR is retained by the creators or other copyright holders. Terms and conditions for use of this material are defined in the End User Agreement.

\section{www.reading.ac.uk/centaur}

\section{CentAUR}

Central Archive at the University of Reading

Reading's research outputs online 


\section{Accepted Manuscript}

Seafood Safety and Quality: An Analysis of the Supply Chain in the Sultanate of Oman

Moza A. Al-Busaidi, David J. Jukes, Associate Professor of Food Regulation, Shekar Bose, Associate Professor

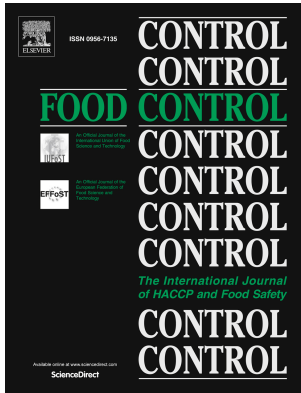

PII:

S0956-7135(15)30050-5

DOI:

10.1016/j.foodcont.2015.06.023

Reference: $\quad$ JFCO 4506

To appear in: Food Control

Received Date: 20 March 2015

Revised Date: 4 June 2015

Accepted Date: 9 June 2015

Please cite this article as: Al-Busaidi M.A., Jukes D.J. \& Bose S., Seafood Safety and Quality: An Analysis of the Supply Chain in the Sultanate of Oman, Food Control (2015), doi: 10.1016/ j.foodcont.2015.06.023.

This is a PDF file of an unedited manuscript that has been accepted for publication. As a service to our customers we are providing this early version of the manuscript. The manuscript will undergo copyediting, typesetting, and review of the resulting proof before it is published in its final form. Please note that during the production process errors may be discovered which could affect the content, and all legal disclaimers that apply to the journal pertain. 


\title{
Seafood Safety and Quality: An Analysis of the Supply Chain in the Sultanate of Oman
}

\author{
Moza A. Al-Busaidi (Corresponding Author) \\ University of Reading \\ Department of Food and Nutritional Sciences, Whiteknights, Reading RG6 6AP, UK \\ E-mail: M.A.A.Al-Busaidi@reading.ac.uk \& moza_albusaidi@yahoo.com
}

David J. Jukes

Associate Professor of Food Regulation

University of Reading

Department of Food and Nutritional Sciences, Whiteknights, Reading RG6 6AP, UK

\author{
Shekar Bose \\ Associate Professor \\ Sultan Qaboos University
}

Department of Natural Resource Economics, College of Agricultural and Marine Sciences.

P.O.Box 34, Al-Khod, Postal Code 123 Muscat, Sultanate of Oman 
1 Moza A. Al-Busaidi (Corresponding Author)

2 E-mail: M.A.A.Al-Busaidi@pgr.reading.ac.uk

3

4

\section{Introduction}

Seafood products are essential part of basic food basket in many developing countries with their quality and safety issues inherently linked to the concept of food security (Bose, 2010). Fish and seafood products are considered an important part of a balanced diet and contribute to a good nutritional status. They contain high levels of many important nutrients not commonly found in other foods. Seafood is known to be an excellent source of proteins, very long-unsaturated chains of omega-3 fatty acids (EPA and DHA), vitamin D, vitamin B12, and many useful trace elements such as selenium and iodine. However they also pose significant safety risks and the rapid increase in globalization of fish production and trade has led to concerns and international incidents of contaminated fish (James, Ababouch, \& Washington, 2013).

The Sultanate of Oman, located on the eastern edge of the Arabian Peninsula, has a long coastline with rich fishing grounds. The issue of seafood safety and quality has become a priority for the Omani government which is concerned about the ability of the country to guarantee the safety and quality of their fish and seafood products. Furthermore, the rapid development of tourism industry in Oman has increased the need to develop an efficient food control infrastructure within Oman. This needs to be capable of ensuring that exports meet the legal requirements and the high standards demanded by international markets but also providing protection for those consuming the products locally (whether as tourists or the local population).

For many centuries, fishing in Oman has been an integral part of its culture and providing both employment and income opportunities as well as nourishment for the majority of the Omani population. Under the 8th Five-Year National development Plan (2011-2015) the Ministry of Agriculture and Fisheries (MAF) has stipulated key strategic approaches to advance the development of the fisheries sector and to increase its contribution to the Gross Domestic Product (GDP). Effective management of the supply chain is seen as a necessity to reduce post-harvest losses and enhance the quality and safety of locally produced seafood as well as ensuring the integrity of imported and exported seafood products.

This study analyses the current seafood safety and quality issues facing the Omani fishing industry and food control authorities. It develops proposals for the development of this sector by the government and the private sectors in order to enhance food safety standards and to achieve a proper utilization of the country's vast marine resource.

\section{Overview of the fisheries sector in the Sultanate of Oman}

Historically, the fisheries sector in Oman has been dominated by small-scale fishermen and retailers with some commercial fishermen. Recently, aquaculture farms and fisheries 
establishment become important. The changes have been part of the government's strategic plan to diversify the country's economy and promote private investment (MNE, 2007a, 2007b). The fish harvesting practices in most of the coastal communities have remained the same over the years and the government's goal is to shift the sector from the traditional practices to more modern systems(Bose, 2010).

46

47

48

49

50

51

52

53

54

55

56

57

58

59

60

61

62

63

64

65

66

67

68

69

70

71

72

73

74

75

76

77

78

79

80

81

82

\subsection{Economic status of the fisheries sector}

The fisheries sector is considered one of the most important non-oil sources of income for Oman although its contribution to the GDP is only 0.5 percent and, combined with agriculture, the figure is still only 1.2 percent (NCSI, 2013; WTO, 2013). However, the social impact of this sector is immense particularly in rural development, employment and food security. Most Omani people live in the coastal areas and fisheries provide livelihoods to around 40,000 Omanis directly with about 280,000 individuals depending indirectly on fisheries income (FSB., 2013; Worldfolio, 2012). The continuous growth in production of the agricultural and fisheries sectors has led to their contribution to the provision of food to nearly $39.5 \%$ of the Omani total food consumption during the period from 2009 to 2012(MAF, 2012).

The continuous growth in production of agricultural and fisheries sectors have led to an increase in the contribution in the provision of food, hence both sectors contribute to around $39.5 \%$ of the total consumption food in Oman during the period from 2009 until the year 2012

Fisheries production contributes to the national economy and there is a need to diversify the national income through the development of the fisheries-related industry and enhancement of the future production is crucial. Seafood is a major commodity in international trade and has significant potential for revenue generation. This does though require the industry to adjust its practices to meet regional and international demands for quality and safety. In addition it can be noted that there is potential for overfishing due to the possible financial rewards. International controls for Illegal, Unreported and Unregulated (IUU) fishing have been agreed and Oman is adopting these (RECOFI, 2009; Royal Decree No. 26/2013, 2013). The extent of the problem is, by its nature, unquantified but it is considered not to represent a major fish safety issue and is not considered further in this paper.

In 1995, the country introduced a long-term national economic strategic plan known as "Oman Vision 2020" which specifically aimed to reduce the economic dependency on hydrocarbons sources including an increase the share of the non-oil sector to 15 percent of GDP by 2020 (WTO, 2013). The diversification of the economy has been a vital pillar in the economic policy of the Vision, with objectives of creating an economy that is founded on renewable resources and a highly integrated part of the world economy (WTO, 2013). This strategic decision has diverted attention to the socio-economic potential (i.e., contribution to the Gross Domestic Product (GDP), foreign exchange earnings, employment creation and food security) of the fisheries sector. In order to fulfil this vision, industrial estates, free zones, fish harbours and well-structured landing sites were identified as necessary to support the sector's growth. 


\subsection{Fisheries sector}

The fisheries sector in Oman can be sub-divided into three: the artisanal, commercial fisheries and aquaculture sector.

\section{Artisanal fisheries}

The artisanal fisheries are small scale fishermen operating small vessels (5-9 meters in length) typically made of fiberglass or larger traditional wooden boats known as dhows which are still in use in some governorates. In total these fisheries produced $98 \%$ of the catch in 2013. This sector supports around 44,500 fishermen operating 21,300 fishing vessels (FSB., 2013). Most of these vessels are managed by family members although in some cases either local or expatriate workers are used (A. Omezzine, Zaibet, L., Al-Oufi, H.,, 1996).

\section{Commercial fisheries}

Commercial fisheries comprise recently developed coastal fisheries, long-liners (ships using lines rather than nets) and international contracted trawlers (using nets) targeting the higher value fish products. However, in mid-2011 restrictions were imposed by the government on these fishing trawlers in order to prevent overfishing and ensure a sustainable environment for the fisheries. To replace these, a new fleet of local coastal fishing vessels was introduced and operated by local investors. The aim is to expand its share, which was less than $1 \%$ of the local market - in 2013 it had risen slightly with the commercial fisheries fleets producing $1.3 \%$ (2,710 Tonnes) of the total catch as shown in Figure 1 (FSB., 2013).

\section{Aquaculture Production}

In the Sultanate of Oman, aquaculture is in its infancy stage of development with the aquaculture production small in comparison to the contribution from capture fisheries (FAO, 2006). Early attempts took place in 1986 with a production trial of the giant tiger prawn (Penaeus monodon) but it was halted due to technical difficulties. In 2003 and 2004, commercial cultured fish commenced and the production increased from 352 tonnes in 2003 to 517 tonnes in 2004, with the production of gilthead seabream (Sparus aurata) representing 89 percent of the total production (Table 3). In the same year, tuna farming was launched producing 14 tons of yellowfin tuna (Thunnus albacarus), thus, becoming the first country in the Middle East to have a project of this kind (ESCWA, 2007). In 2007, the Omani government with FAO collaboration developed a national strategy for aquaculture development in the country (FAO, 2006). Describing this in 2012, the Minister of Agriculture and Fisheries stated "As worldwide demand for fish and shellfish is on the rise amidst stagnating yields from traditional capture fisheries due to depleted wild ocean stock, aquaculture holds the key to meeting global seafood supply needs over the coming years" (Worldfolio, 2012). With cultured species, priority has been given to species found locally in Omani waters, and to exotic species with high commercial values which are required to be screened prior to approval. Aquaculture has been gaining momentum in the last ten years (2003 to 2013) with the introduction of new species. Penaeus indicus has shown a steady growth reaching 350 Tonnes in 2013 and destined for domestic and regional markets. However efforts are also being made to target the more lucrative markets such as the EU. Sustainability in this sector is the 
primary aim for aquaculture governance in order to prosper over an extended period, thus viable economically.

\subsection{Production, consumption and trade}

The annual production of the caught and cultured fisheries has increased in recent years mounting from 95,000 Tonnes in 1985 to 206,000 Tonnes in 2013 (FSB., 2013) with total values rising from just R.O 25 million (US \$ 65million) to R.O 166 million (US \$ 431million) within the same period. In 2013 the revenues from export were R.O 97 million (US $\$ 252$ million) which represents $0.5 \%$ of the total GDP (NCSI, 2013). The increase has largely been achieved by government support to the coastal fishermen (ESCWA, 2007). Despite the low contribution of the sector to the GDP, its socio-economic effect is considered significant and thus receives attention in the country's economic development campaign (Qatan, 2010). The annual per capita consumption of fish in Oman is estimated to be $20.2 \mathrm{~kg}$ (FSB., 2013), higher than the world figure of $17 \mathrm{~kg}$ in 2007 (FAO, 2010).

Oman is regarded as a net exporter of fish products with around $61 \%$ of its production in 2013 exported mainly to neighbouring Gulf countries (FSB., 2013) as shown in Table 1. In 2013, Oman exported 125,000 Tonnes to 49 countries around the globe. Most of the exports by volume were to the Gulf Cooperation Council (GCC) (70\%) followed by Asian countries (18\%) with only $2.2 \%$ exported to EU. Although not showing in Table 1 , the proportion of exports to the highly valued national markets of the USA and Japan were tiny representing $0.03 \%$ and $0.05 \%$ of all exports respectively, and less than $1 \%$ in quantity. This clearly demonstrates the opportunities available for market expansion and product diversification.

In comparison, imports are small (less than $10 \%$ of the quantity of exports) and primarily restricted to fish species which are either unavailable locally or subject to seasonal shortages. The majority of the imports are derived from the GCC, and other countries, followed by the Asian countries as shown in Table 1 .

152

153

154

155

156

157

158

159

160

161

162

163

164

165

166

167

168

\section{The seafood supply chain}

The marketing of seafood in Oman is complex linking fishermen, transporters, traders, processors, exporters, retailers and consumers. Based on our knowledge of the Omani fish supply chain and discussions locally, we have developed the overview diagram shown in figure 2 . The main elements of this will now be considered.

\subsection{Fisheries Producers}

As already discussed, the artisanal fisheries account for most of the fresh fish produced in the country. These vessels however lack adequate handling and storage and the fish are usually offloaded onto the beaches or at landing centres of varying standards. The product is frequently sold direct to consumers who enjoy eating fresh fish and they will often make their purchases direct from the fishermen despite the presence of local fish markets. Other fish will be sold to traders or processors with auctions being held at some landing centres (Qatan S., 2010).

The overall marketing system in Oman consists mainly of the coastal fish markets ('primary'), fish markets in the interior parts of the country ('secondary'), retail markets and recently a central market in Wilaya Barka. Primary markets are typically basic structures lacking services and are mostly located at the landing centres with fish offloaded directly 
from the boats of the local fishermen. Sales from these markets can be both retail and wholesale and depend on the fish species, the quantity involved and the clients (household or commercial). Until recently all markets with the exception of the retail outlets were under the jurisdiction of the local municipalities but a government decision in 2011 reallocated control of them to the MAF. This is part of moves to bring the entire seafood supply chain under one authority and improve procedures throughout the chain. The municipalities still control the retail markets and the super- and hypermarkets and supply fisheries products to the different regions and interior governorates. They can vary in capacity and infrastructure and are still under the jurisdiction of the different municipalities. Currently 60 primary and secondary fish markets exist in the country and the Ministry is developing minimum requirements covering structure hygiene and procedures which are progressively being implemented throughout the country.

As recommended by various studies (Al-Jufaili M. Saud and Opara Linus U. , 2006; Al-Jufaili, 2006; A. Omezzine, 1998; A. Omezzine, Al-Oufi, \& Al-Akhzami, 2004), in order to improve the supply, safety and quality of fish for the internal and external supply chain, a large scale wholesale fish market has been constructed by the MAF and the Muscat Municipality with full modern services such as electronic auctioning, fish quality checking, ice machines, potable water, hygienic containers, display areas, facilities for monitoring temperature, sanitary inspections and etc... Further small wholesale markets have been established and it is planned to connect all three electronically to assist buyers and sellers. As well as facilitating trade of local fish, these central markets will in future be used for imported and aquaculture fish. This will ensure that these products are properly labelled and checked before entering the local market. Controls on transportation to the central market have been weak and it is planned to extend controls to this in the near future. Enhanced legislation for the organisation of fish markets has been recently issued by the MAF (MD No. 312/2014).

Most of imported fish products are sold at the retail markets with some going via the primary and secondary fish markets and some being directly imported by processors as raw materials for their added-value production and for re-export particularly in the low production seasons.

The transport systems play an important role in the fresh fish supply chain. The transporters, sometimes described as middlemen, use specific trucks to collect fresh fish products from different primary markets at the landing centres with direct collaboration with fishermen. They then distribute the products to secondary, central, retail markets, processors and consumers with a larger portion being transported to neighbouring countries. Some of the larger trucks have refrigeration and transport large quantities of fisheries products covered with ice within insulated boxes but the majority lack these facilities. This creates food safety issues due to poor handling and inadequate cold chain control. Legislation has been adopted to regulate the conditions and specifications for transportation (MD No. 29/2004) but has not been fully implemented. However it is expected that a Ministry funded project will shortly upgrade the transportation to meet the regulatory requirements. Products intended for export to international markets (i.e. the EU and USA) where stringent safety and quality controls are required are usually transported using control conditions by approved transporters with the processors collecting the fresh fish directly from the fishermen or commercial vessels. 
The seafood processors serve domestic, regional and international customers. The majority of these processors produce mainly fresh and frozen products of different species caught locally. Only a few processors deal with added value products, such as canned tuna and sardine or breaded products, with raw materials obtained from both local and external markets Currently 47 seafood processors are operational with 21 having national certification for export (requiring the adoption of Hazard Analysis and Critical Control Point (HACCP) procedure and its pre-requisite programmes) with the rest at different stages of certification (figure 3). The Quality Control (QC) certificate and related $Q C$ number is granted by the FQCC to the establishments, fishing vessels and fishery transporters when they meet the provisions for export to major international markets set out in MD No. 12/09 (Ministerial Decision, 2009). Processers lacking the quality and safety systems required for certification and a QC number may target other less demanding markets. Aquaculture products are still a small element but usually find their way to the primary and retail markets. Some are produced specifically for export to regional markets and international markets.

\subsection{Domestic, Regional and International Consumers}

230 As shown in figure 2, the supply chain delivers products to consumers in three types of markets: local, regional and international. The first two of these are similar with limited levels of health and safety control; however, these controls intensify as approaching the international market with the EU and USA market considered the most stringent.

234 Domestic consumption of seafood products depends on their availability, income levels, traditions and food perceptions. Fish exports are the most important source of foreign currency rated second after non-oil exports. Policies therefore encourage the trade and a high percentage of the local catch is exported to the neighbouring countries (regional consumers) with the highest quality going to the international consumers. As a consequence, local consumers suffer from occasional fish shortages, despite higher prices being offered for certain commercial fish (Mbaga, Al-Jufaily, \& Al Belushi, 2012). Therefore, the ministry have employed appropriate measures with the local producers in order to regulate the distribution of the seafood products in terms of the pricing and accessibility by domestic markets and reduce inflation due to the elevated fish prices (Bose, 2010).

244 Exports to regional markets have increased in recent years particularly to UAE, Saudi Arabia and other GCC countries. However, the benefit incurred is really low since this is largely fresh unprocessed fish with no added value. It has been suggested that there are opportunities to increase regional trade in added value products leading to more local employment (Mbaga et al., 2012). Transport to these regional markets often lacks appropriate temperature controls and, given the distances involved and the high temperatures, quality and safety of the products suffer resulting in economic losses. Preliminary data for 2014 (personal communication) is showing a reduction in the volume exported to neighbouring countries following the introduction of the wholesale fish market. Providing a more systematic mechanism for the operation and the control of the various fish markets in the country will enable increased efficiency, substantial reduction in the postharvest losses and the exploration of new markets. This will enable the sector to contribute more to the country's economy and enhance its food security. 
For exporting to the EU, USA and Japan the most significant regulations are those of the EU

258 requirements which lay down the health conditions required for the handling and marketing of fishery products (see below).

\section{Seafood Safety challenges}

Seafood products, either wild or farmed, are highly perishable. Their quality degrades rapidly due to the high content of water and easily digestible macro-components. They are susceptible to rapid deterioration and postharvest loss due both to microbial growth and biochemical reactions aggravated by raised temperatures. Other problems are caused by contaminants that are present in the environment where the seafood are grown and harvested.

\subsection{Microbial Contaminants}

269

270 Seafood-borne diseases of microbiological origin are mainly caused by viable organisms and/or ingestion of toxins formed in the food prior to consumption. Microbial and biochemical reactions cause public health risk and arise from specific activities along the harvesting, production and processing supply chain. A study conducted by (Sudheesh, AlGhabshi, Al-Aboudi, Al-Gharabi, \& Al-Khadhuri, 2013) on the hygiene status of Omani seafood retail outlets selling local seafood products revealed the presence of heavy contamination of the food contact surfaces and fish handlers with indicator organisms and pathogenic bacteria and called for improved hygiene controls.

One of the most frequently reported foodborne illnesses associated with seafood is scombrotoxin fish poisoning (SFP) caused by the production of histamine, and other biogenic compounds which is mostly associated with fish species belonging to the following families Scombridae, Clupeidae, Engraulidae, Coryfenidae, Pomatomidae, and Scombresosidae (Regulation (EC) No 2073/2005). These biogenic compounds, once formed, are stable to heat treatments and other preservative methods. High levels are often found when high temperatures occur in the harvesting and supply chain. Research by (Guizani, AlBusaidy, Al-Belushi, Mothershaw, \& Rahman, 2005) carried out on yellowfin tuna (Thunnus albacares) caught from the coastal area of Oman showed that the time and temperature of handling, processing and storage were significant risk factors with respect to histamine production. The study showed that although there is a correlation between a freshness index (the K-value) and sensory/organoleptic changes this cannot be used to predict the presence or absence of histamine.

Fish species belonging to some of the previous mentioned families have a high value and are popular with local consumers in Oman. However, there is a lack of published studies on level of scombrotoxin fish poisoning in the country. The poisoning can be misdiagnosed for other food borne illness and epidemiologically categorized as non-specific food poisoning.

\subsection{Environmental pollution}

In respect to environmental pollution, Oman has long coastline of $3165 \mathrm{~km}$ involving two water bodies with different characteristics. To the southeast is the Arabian Sea, a part of the Indian Ocean and an open body of water which is exposed to seasonal monsoons activities and has high marine production. To the northeast is the Sea of Oman (or Gulf of Oman) which is a strait that links the Indian Ocean via the Arabian Sea to the Strait of Hormuz and 
the Arabian Gulf. Around one third of the world's oil production passes through the Strait of Hormuz (Essa, Harahsheh, Shiobara, \& Nishidai, 2005) and related oil exploration and industry in this coastal area are sources of seawater contamination. Agrochemical residues discharge into both areas and also pose an environmental threat with potential toxicological effects on the marine biota and subsequent risk to public health. Although an upwelling phenomenon triggered by the monsoon climate enriches the water with nutritional components and increases the production of marine organisms, high levels of natural cadmium are also brought into the surface waters by this process. Marine organisms, including fish, can accumulate different contaminants including inorganic and organic pollutants from the marine ecosystems leading to potential food safety issues (M. Al-Busaidi et al., 2011; Al-Raesi H, Ababneh F, \& Lean D, 2007; de Mora, Fowler, Tolosa, Villeneuve, \& Cattini, 2005; de Mora, Fowler, Wyse, \& Azemard, 2004; Fowler SW, Villeneuve J-P, Wyse E, \& S., 2007; Tolosa et al., 2005).

A study of fish and shellfish collected from coastal areas of Oman (Moza Abdallah Al-Busaidi, Yesudhason, Al-Mazrooei, \& Al-Habsi, 2012) showed the mean concentration of heavy metals (mercury, lead and cadmium) in the edible muscle of pelagic and benthic species were mostly within the standards set by the EU, FAO and Oman. Elevated concentrations of cadmium above the limits were however reported in fish liver which is due to the physiological role of this organ and in oysters and clams (Poulose Yesudhason et al., 2013). High levels of cadmium in fish livers have been found in elsewhere including Mauretania (Rome et al., 1999), India (Rejimon., 2005; Rejimon et al., 2010; Profula et al., 2001), USA (Monosson \% Lincoln , 2006; Alexander, 1996), Malaysia (Agura et al., 2005), France (Bustamante et al., 1998), Croatia (Kljakovic et al., 2002), Brazil (Paulo et al., 2007), Argentina (Marcovechi et al., 1991,) and Antarctica (Bargagli et al., 1996). This is considered to be due to upwelling phenomena rather than anthropogenic sources.

The country depends on the desalination of the sea water as a source of fresh water supply and therefore control the quality of the marine environment is vital for the country. An emerging threat to desalination and to public health is the formation of Harmful Algal Blooms (HABs) commonly known as red tides. HABs occurrence in the Sea of Oman and the Arabian Sea were reported as early as 1988 following a massive fish kill due to other types of algae blooms (Thangaraja, Al-Aisry, \& Al-Kharusi, 2007). An outbreak in the Arabian Gulf and Sea of Oman in 2008/2009 was due to the dinoflagellate Cochlodinium polykrikoides and lasted nearly eight months. The impact was great with massive loss of fish, damage to coral reefs, restricted fishing and problems in the operation of the desalination plants in Oman and the United Arab Emirates (UAE) (Richlen, Morton, Jamali, Rajan, \& Anderson, 2010). Oman is planning to enlarge its mariculture activities and investing in aquaculture as an alternative to seafood. These activities may increase the frequency of HABs (Al Gheilani, Kazumi, AlKindi, Amer, \& Waring, 2011) and therefore, bloom mitigation scheme are crucial. Bivalve molluscs and other marine filter feeders have the tendency to accumulate biotoxins and can retain them for a long time. Marine predators in turn feed on the bivalves and thus become toxic themselves, posing a major threat to public health.

\subsection{Postharvest issues}

As soon as fish and fishery products have been caught, several biological and biochemical changes take place. The changes that take place in fish muscle immediately after death are crucial in determining the quality and safety of the harvested fish products. At the point of death, fish muscle are fully relaxed with an elastic texture that persists for some time before 
the onset rigor mortis (Alasalvar, Shahidi, Miyashita, \& Wanasundara, 2011; Huss H. H., 347 1995). The timing is affected by several factors such as temperature at the time of 348 harvesting and handling and the size and type of fish species (Huss H. H., 1995; Huss, Ababouch, \& Gram, 2003). Mishandling at the different stages of the supply chain can lead to early rejection due to the onset of spoilage. Additionally, post-harvest losses of perishable products such as fish are very significant, especially in developing countries, owing to quality, safety and physical losses. FAO (FAO, 2014b) has estimated that in developing countries these can amount to 10-12 million tonnes and account for around 10 percent of the global production of wild and cultured fish products.

In Oman, dominated by artisanal fisheries and traders, post-harvest losses can be very detrimental both to the contribution fisheries make to the national economy and to the country's sufficiency in terms of food security. With the fisheries activities scattered along the long coast line, artisanal fishermen and retailers adopt simple techniques for harvesting, handling and processing respectively. These are often insufficient to preserve the quality and safety of the harvested fisheries products for long storage periods and consequently limit their market value (Al-Jufaili, 2006).

Various studies and reports indicated inadequacy in cold chain management particularly for freshly landed fish that can be exposed to elevated temperatures $\left(40^{\circ} \mathrm{C}\right)$ for up to $5-7$ hours thus accelerating deterioration of the fish freshness (Al-Jufaili M. Saud and Opara Linus U. , 2006; Al-Jufaili, 2006; Opara Linus U. and Al-Jufaili Saud M., 2006). Furthermore, loses in both quality and quantity limit the profitability and competitiveness of local fishery produce. One study of the tuna supply chain (Al-Jufaili M. Saud and Opara Linus U. (2006) suggested that shelf life is limited to 3 days by the current postharvest practises. They confirmed the need to upgrade the existing postharvest procedures and to apply modern cold chain technology to overcome loses and extend shelf-life. One consequence of the short life is that often downgraded fish are used to produce secondary fish products (such as salted or dried products) so as reduce the losses faced by the fishermen and traders - this though can lead to further safety issues. Some of these traditionally processed fish products are often associated with the presence of the carcinogenic compounds nitrosamines (Al Bulushi, Poole, Deeth, \& Dykes, 2009; Zou, Lu, \& Liu, 1994) even though the factors influencing their formation have not been well defined. Therefore, the need for proper handling and processing is critical in assuring the health of end users.

\section{Regulatory Framework}

Although seafood consumption contributes to health and wellbeing, concerns at the safety and quality of seafood have been at the forefront of regional and global campaigns and ensuring the safety of this seafood is critical requiring national and international action. For Oman, compliance with respect to safety and quality criteria is vital to access the lucrative export markets and sustain international competitiveness. The EU, USA and Japanese markets are the world's major importers of seafood products with imports accounting for 63\% (AIPCE-CEP, 2014), 60\% and $54 \%$ (FAO, 2014c), respectively of their fishery product consumption. They are therefore important markets for exporters but the situation is complicated since the requirements of each international market differ in terms of the specification and the regulations imposed. 
391 As well as managing the entire fisheries and aquaculture industries including the ports and landing sites, the Ministry of Agriculture and Fisheries (MAF) governs seafood safety in the country. Most recently, in 2011, responsibility for the fish markets has also been transferred to it. The MAF has links with other governmental organizations to try and ensure the safety and quality of fish products with the combined activity attempting to ensure effective surveillance of the fish supply chain.

According to a Memorandum of Understanding (MoU) signed between the Omani government and the European Commission (EC), the MAF has been designated as the Competent Authority (CA) representing the Omani Government on seafood safety and legislation issued in the European Union. The MAF, through the Fishery Quality Control Centre (FQCC), has the legal power to evaluate, inspect and issue certificates to guarantee the safety and quality of the products for export to the EU. It is the premier regulatory agency and has responsibility to implement the National Fishery Quality Control Regulation No.12/2009 and related guidelines and international standards.

For the USA, Oman signed an updated Free Trade Agreement (FTA) 2009 which aims to promote economic reform and openness in trade issues (USTR, 2014). Foods imported into the USA must meet the same legal requirements as domestically-produced foods and inspectors may detain shipments of imported products which not in compliance. They are also subjected to Food and Drug Administration (FDA) inspections under the provisions of the U.S. Federal Food, Drug and Cosmetic Act (FFDCA). In addition the US Code of Federal Regulations provides specific regulations for the safety and sanitary procedures and imported fish and fishery products must have been subject to processing with an effective Hazard Analysis and Critical Control Point (HACCP) system operating.

Japan has requirements which are contained in its Food Safety Basic Law (No. 48) initially issued in 2003 but amended by Law (No. 50) in 2006. The Law has adopted a similar approach to that of the EU and the USA with elements taken from Codex. HACCP-based food control regulations have now been included for fisheries processing covering handling, processing conditions, storage and transport. For exports to Japan, Oman has to issue certificates to confirm that these regulations are being met.

\subsection{Omani fishery control regulations}

421 The Marine Fishing and Protection of Living Aquatic Resources Law was promulgated in 4221981 by a Royal Decree (RD) 53/81 and is known as "The Fisheries Law". Subsequently, the 423 Executive Regulations of the Law was issued in 1982 by a Ministerial Decision (MD) No. 3/82 424 and amended in 1994 by a MD No. 4/94. This represents the start of the current control 425 system as illustrated in figure 4 . The law has six sections including definitions, regulation of 426 fishing, protection and development, handling, marketing and processing, violation and penalties and general provisions. The Executive Regulations deal mainly with marine fishing licences, licence fees, protection and development of living aquatic resources, regulation of fishing, preservation, transport and marketing of living aquatic resources, general provisions and penalties.

431 Other relevant legislation includes the Ministerial Decision on the Quality Control Regulation 432 for Omani Fishery Export (MD No. 4/97) which mainly deals with conditions and 433 specifications of exported fishery products and its by-products in regards to the 
preservation, handling and processing of fish products. In 1998, a Ministerial Decision (MD No. 136/98) was issued to enforce quality control regulations for Omani fishery exports and amended the MD No. 4/97 and required the adoption of HACCP system and its prerequisite programmes in seafood establishments intending to export to the EU. This was introduced as in July 1998, following a visit by the EU's Food and Veterinary Office (FVO), the EU had banned the import of fish from Oman and some other GCC states as the existing controls did not comply with the EU's requirements for HACCP implementation (FAO, 2004). Recently, a new regulation has been issued (MD No. 312/2014) by the MAF which covers the organization and operation of fish retail and whole sale markets, seafood products handling, market monitoring in terms of hygiene and safety of the marketed products (Qatan, 2010).

444 The EU's ban was lifted one year later in 1999 (FAO, 2004). Following another FVO mission in 2006, a new MD No. 12/2009 on Fishery Quality Control Regulation was issued in 2009 to amend MD No. 136/98 to ensure equivalence with the EU's requirements on contaminants, additives, potable water, hygiene, and official controls (European Commision, 2006). This regulation contains a wide range of provisions covering the quality control and safety of fish and fishery products for import, export and for the domestic markets (Moza A. Al-Busaidi \& 450 Jukes, 2015).

451 As indicated above, the development of the aquaculture industry in Oman is a key part of the country's plan to diversify its economy beyond the hydrocarbon sector (MAF, 2011). The development of an aquaculture industry will not just increase the production of seafood but could also reduce the over-fishing of highly commercial value species. To ensure the adoption of 'Best management practices (BMP)' and effective control of aquaculture, the government issued a regulation in 2004 (36/2004) which was updated in 2012 (177/2012) (Moza A. Al-Busaidi \& Jukes, 2015). In addition there are environmental laws and regulations that are directly related to aquaculture sector issued by the Ministry of Environment and Water Resources (MEWR). These include Royal Decree RD No. 114/2001 (Law on Conservation of the Environment and Prevention of Pollution), MD No. 187/2001 (Organizing the Issuance of Environmental Approvals and the Final Environmental Permit), RD No. 46/95 (Law of Handling and Use of Chemicals) and finally the MD No. 7/84 on (Disposal of Liquid Effluent to the Marine Environment) (FAO, 2006).

The overall food safety system is structured in various government agencies that are based at different ministries (Moza A. Al-Busaidi \& Jukes, 2015). Therefore, the efforts to successfully dealing with existing and emerging food safety threats and risks are hindered, due to the duplication in mandates and overlapping responsibilities of the responsible agencies. A lack of harmonization of the standards and regulations for the domestic production, exports and imports is a challenge for the regulators and the different stakeholder particularly when considering world trade and consumers protection issues. Ensuring effective legal control for the assurance of hygiene, safety and quality across the all stages of the seafood production chain is fundamental to access the export markets.

473 Faced with many difficulties due to the increase in sanitary and safety regulations 474 highlighted in the world trade of fishery products, regulation (12/09) has broaden its scope 475 from the previous regulation (136/1998). It mandates the enclosed of all the institutions, processors and individual operating in the field of fish and fishery products either exporting, importing or domestic production to adapt their situation accordingly to the stipulated rules of this regulation (Ministerial Decision, 2009). The stringent regulation has imposed 
important socioeconomic consequences on the domestic supply chain. The cost imposed on seafood processing to restructuring their facilities and production lines are significant highly and this has been estimated to amount to R.O. 98,000 (254,545 USD) (Qatan, 2010) and not within the capabilities of these processors. As indicated by the Ministry, a lot of effort is in place to upgrade these establishments to meet with regulation No. 12/09.

\subsection{Food safety management systems}

Seafood safety and quality control measures were not a priority until the EU embargo in 1998. This required enhanced procedures to ensure compliance with the EU legislation. In particular it led to the establishment of the FQCC under the Directorate General of Fisheries Research with headquarters in Muscat and regional offices in various coastal governorates. The FQCC is the premier regulatory agency for the enforcement of seafood safety and quality regulation required by MD No. $12 / 2009$. In addition it is responsible for inspecting, assessing, and approving seafood production vessels and establishments and related activities and for the analysis of samples for contaminants. The veterinarian and quarantine department with the Ministry is responsible for issuing health certificates and certificates of origin to accompany exported seafood consignments in order to ensure their compliance with national laws and regulations. They also inspect seafood products on entry into the country.

In accordance with the new requirements, in 1999 nine plants were certified as HACCP compliant and were provided with Quality Control (QC) numbers and became eligible to export their products to international market, particularly EU and allowed for the lifting of the EU's ban. Subsequently, by 2002, the number of certified plants had increased to 25 plants, accounting $50 \%$ of the total processing fisheries plant, at that time (ESCWA, 2007). However, a decrease in the landing of fish species with higher export values internationally has caused some local exporters to question the value of meeting these enhanced standards. The potential for fishermen to market fish to neighbouring countries with fewer regulatory requirements in preference to selling to local processors has added further to the struggles of companies seeking to export products to major international markets (ESCWA, 2007). Consequently, by 2013 the number of certified plants had declined to 21 .

508 The adoption of HACCP principles by Omani fish processors has not progressed easily. The

509

510

511

512

513

514

515

516

517

518

519

520 government gave a priority to the adoption of food safety management systems, including HACCP, as this was mandatory to meet the international markets' requirements. Implementation of the new legislation was enforced by the FQCC and enhanced infrastructure facilities (such as new icing plants and improved fishing harbours) were put in place. Additional laboratories were constructed for the FQCC for the testing for contaminants, whether microbial, chemical or physical. A specialist department on seafood safety systems implementation was set up within the FQCC to provide technical assistance to the private industries to ensure their conformity with regulation guidelines of such things as product flow, overall structure and HACCP implementation. Training on hygienic fishhandling practices, prerequisite programmes (Good manufacture Practices (GMP) and Good Hygiene Practices (GHP)) HACCP and others matters has been conducted for the different stakeholders in the fish supply chain.

One study has identified some weaknesses and constraints that reduce the effectiveness of the regulatory systems in the seafood sector (Qatan, 2010). The study highlighted the lack of pro-activeness and dependency of the seafood processors on the regulatory authority of the 
524 food safety management system. The study highlighted the difficulties faced by the industry

525 in terms of the cost of HACCP implementation, in fish processor for the structural work and

526 the modification required to meet the regulation requirements.

527 Work to upgrade existing seafood establishments continues but progress has been slow due

528 to resource constraints and the scattering of responsibilities in the different government

529 agencies. It can be noted that HACCP is not mandatory for most food processors so

530 persuading companies to adopt the system for export purposes can be difficult.

531 For imported fishery products, the FQCC's laboratories are the primary authority for 532 sampling and analysis but liaise with other food control laboratories in the country. 533 However although the FQCC's laboratories follow procedures (sampling plans and testing 534 methods) established to meet the requirements for export, the other laboratories only 535 apply procedures established for sales in Oman. Therefore, these products are treated 536 differently with less stringent requirements in order to ease the cost burdens on the producers and in most of the cases produced in non-HACCP certified processors.

538

539

540

541

542

543

544

545

546

547

548

549

550

551

552

553

554

555

556

557

558

559

560

561

562

563

564

565

\section{SWOT analysis}

The above sections have provided key information on the major elements of the fishery supply system in Oman, the regulations and controls applied to it as well as the management systems adopted within the sector. The ministry has worked hard to upgrade this sector and reduce the postharvest losses caused during fisheries production. Much has been achieved. However it is also clear from the above description that despite a desire by the Omani government to increase its export trade, the process has not been easy and still provides challenges.

In order to try and identify what more the government could do for the industry to make it more successful, we have used the information given above to construct a SWOT analysis identifying the Strengths, Weaknesses, Opportunities and Threats to the fishery sector in Oman. This has been tabulated in Figure 5 .

\section{Discussion}

Fisheries production is one of the countries' chief sources of economic revenue after oil production. The country exported $60 \%$ of its production in 2013 with most of the exports targeting regional markets such as the GCC countries as well as Asian and African countries. The lucrative markets of the EU, USA and Japan on the other hand, are less targeted due to the more stringent standards imposed by the importing countries. Gaining access to these markets can be costly as it requires the adoption of enhanced controls such as HACCP and other management standards and exporters face high competition for market share from other countries seeking to export. Despite the costs, HACCP does have significant benefits (Taylor, 2001). A correctly applied HACCP system gives a food business operator in depth knowledge of the potential hazards in the process. They also become more focused on the essential controls needed in their processing plants such as critical control points rather than depending on the end products testing which is expensive and does not prevent product failure. In the long run as stated by (Taylor, 2001) despite the work of initially 
setting up a HACCP system, costs can be reduced. Most of all, if implemented correctly, the system provides the food industry with effective management tools to produce safe food and prevent foodborne illnesses. As the internationally recognised food safety system, its adoption provides a clear benefit as it allows access to a wide range of international markets (Taylor, 2001). A local study by (Qatan, 2010) had findings which were in agreement with these. The main benefits of HACCP ranked by authority and the seafood industries were the improvement of the safety and quality of the products; easy access to lucrative markets with stringent food safety requirements in place; improved customer satisfaction and moral and commitment to the food safety and quality. Whilst a reduction in the rejections of seafood products entering the EU and international markets was observed by both groups after the implementation of HACCP in the seafood industry in Oman.

577 Domestic factors such as price, income distribution, consumer preference and availability, also have an effect on the demand of fisheries products, therefore, leading to uncertainly as to the availability of supplies.

580 Oman has made progress toward the implementation of these higher standards and has

581

582

583

584

585

586

587

588

589

590

591

592

593

594

595

596

597

598

599

600

601

602

603

604

605

606

607

608

609 been introducing enhanced management systems into the industrial sector. The existence of strengthened legislative and government support, including subsidies, has encouraged some businesses to implement HACCP despite not being a necessity for the local market. The lifting of the EU's ban within a year of its imposition demonstrates that much can be achieved in a short time when necessary. However, although progress was made in the implementation of HACCP processes, difficulties still arise in the enforcement of this system throughout the seafood supply chain due to the inadequate capability of some of processing plants particularly the smaller businesses.

\subsection{Flow process of fisheries products}

Maintaining high quality seafood products is very critical and vital in order to stay accessing the global market (World Fish Center, 2005). Certain traditional methods of harvesting, preservation and processing for fishery products cannot meet the requirements of the global market. Innovation in the pre- and post-harvesting process is vital in order to reduce production losses and enhance the quality and safety of the final products. As the weaknesses in the sector have been recognized, support will be required to make the urgent improvements necessary to advance the fisheries industry

The existence of appropriate facilities for fishing vessels, landing, storage, distribution and marketing is crucial for the quality and safety of the end products produced in this sector and in order to meet the requirements of the legislation. As well as technical and financial support, the industry requires training, education and information to ensure successful trading. A greater use of commercial fisheries, rather than artisanal, would also increase production capacity and help meet the government's goal of increasing the contribution of fisheries to the overall national economy.

It is clear that the traditional fisheries need to invest in more advanced boats with preservation and storage facilities on board. This would be most appropriate in the Arabian Sea coastal areas where fish stocks are more likely to be sustainable. Basic hygiene requirement and good infrastructure should be enforced in all the onshore (primary), secondary markets and small processing plants. The transport system must comply with the conditions and specifications of the living aquatic resources transportation and marketing 
vehicles of MD No. 29/2004. The high temperature environment in the country makes compliance with temperature requirements very difficult when combined with current practices of pre- and post-harvest techniques and the simple infrastructure found in certain regions. Effective cold chain management retards microbial and biochemical reactions associated with food spoilage and deterioration and reduce production losses and enhance 615 the quality and safety of products.

616 National and international safety and quality requirements are usually met by those 617 stakeholders who currently operate in the major international markets. However, the 618 findings of this study indicate that many aspects of the supply chain in Oman fall well below this. The most likely causes of this is the cost incurred in raising standards to comply with the international requirements resulting in increased production costs which also impact on products destined for the domestic and regional markets. The costs are only recovered when the fish products are exported to foreign markets. Therefore, earning foreign currency by exporting to neighbouring countries is less risky and much easier and so a higher percentage of the local catch is now going in that direction. As this market has expanded, local consumers have suffered from occasional fish shortages in the domestic market and, if available, often it is of poorer quality.

627 In order to reduce post-harvest losses, fisheries resources have to be managed by applying 628 the correct handling practices both on board and throughout the supply chain (FAO, 2014a). The conversion of low-value fish to value added products is another alternative to reduce losses (FAO, 2014a) and increased income with the generation of more employment in the country (Mbaga et al., 2012). The construction of more central markets will overcome market constraints by providing well organized and controlled channels between the wholesalers and the retailers (Qatan S., 2010). Currently a constraint in the seafood supply chain in Oman is that the harvesting area is often the only information supplied by the producers. Establishing labelling systems in these markets will facilitate chain traceability from harvest through the chain giving products with enhanced quality and safety attributes.

\subsection{Seafood safety issues}

638

639 The globalization and liberalization of the world fish trade has brought benefits and challenges for food safety (World Fish Center, 2005). In developing countries such as Oman, these benefits and challenges are seen mostly prominently in the complex stages of the supply chain (fishermen, fish farmers, marketing, processing, distributers, consumers and the government). The increased demand for fishery products and the growing aquaculture industry in the country requires enhanced controls with HACCP, and its pre-requisite programmes, mandated from farm to fork. Seafood products are often exposed to a poor handling and a lengthy distribution chain before reaching consumers and, given its perishability; its safety can be easily compromised if inadequately controlled. Environmental contaminants levels, on the other hand, must be regulated through continuous surveillance programmes at the harvesting and farming areas before entering the supply chain to ensure the highest level of consumer health protection. Consumer education and awareness program are essential and can be used as a driving force in improving the general status of food safety in the country. The FAO has also been working to provide additional guidance to countries seeking to enhance their fisheries control operations. In particular they have published "Guidelines for risk-based fish inspection" (FAO, 2009) which contains valuable guidance on these matters. 
Although seafood products can be of great health benefit in the diet they also carry risks to public health. They are responsible for notable outbreaks of food-borne disease worldwide. Prevention and control strategies are essential to define the causative agents and enable effective measures to reduce their incidence. Coordination between food safety regulators and epidemiologists will be crucial in Oman (Moza A. Al-Busaidi \& Jukes, 2015) in order improve current and future prevention strategies.

\subsection{Safety legislation}

663 Food control authorities have a duty to ensure the integrity and safety of foods offered to 664 the consumer. The Codex Alimentarius Commission has endorsed the adoption of HACCP as a system for ensuring the safety of foods and the prevention of foodborne diseases. In addition, a series of Codes of Practice for fisheries products have been developed to aid the fisheries industry. The World Trade Organization's Agreements on the Application of Sanitary and Phyto-sanitary Measures and the Technical Barriers to Trade has urged both government and industry to harmonize and adopt transparency in order to minimize barriers to international trade. Oman, as a member of both organizations since 1972 and 2000, respectively, has adopted sanitary and safety regulations based on Codex, WTO and the EU's requirements and recommendations. This has included work by the MAF implementing measures specifically to carry out quality and safety control and inspections of the seafood industry.

On the basis of the Regulation No. 12/2009 addressing specific rules for official controls on fish and fishery products, seafood processors and their related activities are mandated to upgrade their systems to meet the expected requirements. However, despite the existence of a well-defined legal framework throughout the seafood supply chain, there has only been partial implementation of modern food safety management systems in the country.

679 The extension of the requirements of the regulations (No. 12/2009) to cover the full supply 680 chain and the broadening of the requirements to include importers, exporters and local producers has spread the resources more thinly. The latest inclusion of the fish markets into the mandate of the MAF has also increase the burden on the limited number of official regulators. The system is still complex with food safety laws and regulations fragmented among different governmental authorities and functioning as multi-agency system (Moza A. Al-Busaidi \& Jukes, 2015). These delays the adoption of a fully risk-based approach meeting the food safety challenges for both its domestic and potential export markets.

\section{Conclusion and recommendations}

The fisheries sector is one of the most important non-oil sources of income for the Sultanate of Oman. Small-scale fishermen are the backbone of fisheries production particularly with the absence of a robust industrial fishery in the country. The MAF has tried various approaches to enhance the fisheries sector in order to meet the stringent requirements of international trade. HACCP has been highly recommended in the Omani's fisheries legislation and efforts continue to protect both the health of the consumers and the interest of its industry.

696 To ensure seafood safety and quality the supply chain must incorporate the best practice on 697 board and during handling of seafood products (e.g. cleaning, bleeding and ice). Traceability 
techniques from the primary producer (wild and farmed), through post-harvest treatment, processing and distribution to the consumer must be developed and attained. With the development of the aquaculture industry in the country, an increasing emphasis on the prevention of hazards at source will be essential. These could be developed and disseminated through good aquaculture practices and the application of HACCP in the different stages of the process to complement the existing methods. Regional collaboration among the different GCC countries sharing the same water bodies, perhaps within the Regional Organization for the Protection of the Marine Environment (ROPME) framework, Regional Commission for Fisheries (RECOFI) or Gulf Cooperation Council (GCC) food safety committee would also be of great benefit to overcome safety problems. Some of the collaborative work could be environmental programmes involving surveillance to monitor the various contaminants in the marine ecosystem and preventing them from entering the food chain. It is suggested that an annual 'food safety awareness week' be held in all GCC countries at similar times and used as a platform to launch various programs for educating and communicating with different stakeholders in the food supply chain. Further efforts to unify the official food control system both in Oman and across the different GCC countries would also assist consumer wellbeing.

In order to achieve similar levels of protection against foodborne hazards, stringent safety and quality requirements should be enforced equally from farm to fork covering all aspects of harvesting, production and distribution regardless of the target market or consumers. Harmonization of food safety legislation and policies is fundamental for the unification of food control efforts in order to apply measures to protect human wellbeing.

720 For various reasons food safety standards differ amongst countries, in particular between 721 developed and developing countries. These include the way food safety is perceived, climate differences, type of potential risks involved, process technology and the control mechanisms. Food safety standards have often been perceived as a barrier to trade impeding the developing countries access to valuable markets (Henson \& Jaffee, 2008). However, an effective food safety and quality assurance system is of paramount importance for the protection of both the health of the consumers and the interests of industry generally. Moreover, these standards should perhaps be viewed as a catalyst rather than a barrier. Although they pose challenges, they also provide opportunities to developing countries to upgrade and develop their systems, to be more efficient and effective in controlling food safety and quality as well as ensuring conformity with international standards and specifications (Henson \& Jaffee, 2008).

732 Considering the importance of the seafood industry in Oman, the government has recognized the benefits of adopting this approach into its fisheries industry and viewing it as a catalyst. When EU banned its fisheries export in 1998, it responded by reforming its food safety controls and quickly regained market access. Adopting a proactive approach to seafood safety is a sound strategic response to establish a position in the global market.

737 Our research will continue and seek to identify more precisely the benefits and constraints 738 in implementing food safety management systems in the seafood industry in Oman. 
The authors are grateful for the valuable information and data provided by the officials form the Ministry of Agriculture and Fisheries in Oman. This study is supported by fund (F3168478) from the Ministry of Higher Education in Oman.

\section{References}

AIPCE-CEP. (2014). Finfish Study. EU Fish Processors and Traders Association. Brussels January 2015. Al-Busaidi, M., Yesudhason, P., Al-Mughairi, S., Al-Rahbi, W. A. K., Al-Harthy, K. S., Al-Mazrooei, N. A., \& Al-Habsi, S. H. (2011). Toxic metals in commercial marine fish in Oman with reference to national and international standards. Chemosphere, 85(1), 67-73.

Al-Busaidi, M. A., \& Jukes, D. J. (2015). Assessment of the food control systems in the Sultanate of Oman. Food Control, 51(0), 55-69.

Al-Busaidi, M. A., Yesudhason, P., Al-Mazrooei, N. A., \& Al-Habsi, S. H. (2012). Bio-monitoring of Heavy Metals and Chemical Contaminants in the Aquatic System of Oman Report for the period of April, 2009 to March, 2012. Fishery Quality Control Centre (FQCC), Ministry of Agriculture and Fisheries Wealth. Agriculture and Fisheries Development Fund (AFDF).

Al-Jufaili M. Saud and Opara Linus U. . (2006). Status of Fisheries Postharvest Industry in the Sultanate of Oman: Part 3. Regression Models of Quality Loss in Fresh Tuna Fish Journal of Fisheries International, 1(2), 141-143.

Al-Jufaili, S., M, \& Opara, Linus, U, . (2006). Status of Fisheries Postharvest Industry in the Sultante of Oman: Part 1- Handling and Marketing Systems for Fresh Fish. Journal of Fisheries International, 1(2-4), 144-149.

Al-Raesi H, Ababneh F, \& Lean D. (2007). Evaluating mercury biomagnification in fish from a tropical marine environment using stable isotopes (13C and $15 \mathrm{~N})$. . Environmental Toxicology and Chemistry 26: 1572-1581.

Al Bulushi, I., Poole, S., Deeth, H. C., \& Dykes, G. A. (2009). Biogenic amines in fish: roles in intoxication, spoilage, and nitrosamine formation--a review. Critical Reviews in Food Science and Nutrition, 49(4), 369-377.

Al Gheilani, H. M., Kazumi, M., AlKindi, A. Y., Amer, S., \& Waring, C. (2011). Fish Kill Incidents and Harmful Algal Blooms in Omani Waters. Agricultural and Marine Sciences, 16, 23-33.

Alasalvar, C., Shahidi, F., Miyashita, K., \& Wanasundara, U. (2011). Handbook of seafood quality, safety and health applications.

Bose, S., Al-Mazrouai, A., Al-Habsi, S., Al-Busaidi, I. and Al-Nahdi, A.,. (2010). "Fisheries and food security: the case of the Sultanate of Oman". Paper presented at the International Conference on Food Security in the Arab Countries: New Challenges and Opportunities in the Context of Global Price Volatility, March 2-4, Sultan Qaboos University, Muscat, Sultanate of Oman.

de Mora, S., Fowler, S. W., Tolosa, I., Villeneuve, J.-P., \& Cattini, C. (2005). Chlorinated hydrocarbons in marine biota and coastal sediments from the Gulf and Gulf of Oman. Marine Pollution Bulletin, 50(8), 835-849.

de Mora, S., Fowler, S. W., Wyse, E., \& Azemard, S. (2004). Distribution of heavy metals in marine bivalves, fish and coastal sediments in the Gulf and Gulf of Oman. Marine Pollution Bulletin, 49(5-6), 410-424.

ESCWA. (2007). Trade and environment dimensions of the fisheries sector in the Arab Countries: the case study of Yemen and oman. United Nations, New York: ESCWA.

Essa, S., Harahsheh, H., Shiobara, M., \& Nishidai, T. (2005). Chapter 3 Operational remote sensing for the detection and monitoring of oil pollution in the arabian gulf: Case studies from the United Arab emirates. In M. Al-Azab \& W. El-Shorbagy (Eds.), Developments in Earth and Environmental Sciences (Vol. Volume 3, pp. 31-48): Elsevier.

European Commision. (2006). Final report of a mission carried out in Oman: DG(SANCO)/8232/2006 - MR Final. 
FAO. (2004). Food Safety and International Trade in the Near East Region: In Paper presented at Twenty-seventh FAO Regional Conference for the Near East. Doha, Qatar: Food and Agriculture Organization.

FAO. (2006). National Aquaculture Sector Overview. Fisheries and Aquaculture Department.

FAO. (2009). Guidelines for risk-based fish inspection. FAO United Nations, Rome.

FAO. (2014a). Fisheries and Aquaculture Department. Retrieved May 14, 2014., from $<$ http://www.fao.org/fishery/en>

FAO. (2014b). Post-harvest changes in fish. Retrieved Oct 20, 2014, from $<$ http://www.fao.org/fishery/topic/12320/en>

FAO. (2014c). The State of World Fisheries and Aquaculture: Opportunities and challenges. Food and Agriculture Organization of the United Nations Rome, 2014.

Fowler SW, Villeneuve J-P, Wyse E, J. B., \& S., d. M. (2007). Temporal survey of petroleum hydrocarbons, organochlorinated compounds and heavy metals in benthic marine organisms from Dhofar, southern Oman. . Marine Pollution Bulletin 54: 357-367.

FSB. (2013). Fishery Statistics Book Fisheries Statistics Department, General Directorate of Planning \& Development.: Ministry of Agriculture and Fisheries, Sultanate of Oman.

Guizani, N., Al-Busaidy, M. A., Al-Belushi, I. M., Mothershaw, A., \& Rahman, M. S. (2005). The effect of storage temperature on histamine production and the freshness of yellowfin tuna (Thunnus albacares). Food Research International, 38(2), 215-222.

Henson, S., \& Jaffee, S. (2008). Understanding developing country strategic responses to the enhancement of food safety standards. The World Economy, 31, 548-568.

Huss H. H. (1995). Quality and quality changes in fresh fish. FAO FISHERIES TECHNICAL PAPER No. 348(FOOD AND AGRICULTURE ORGANIZATION OF THE UNITED NATIONS, Rome. ).

Huss, H. H., Ababouch, L., \& Gram, L. (2003). Assessment and management of seafood safety and quality. FAO Fisheries Technical Paper(444), i-vii, 1-230.

James, D., Ababouch, L., \& Washington, S. (2013). Risks and benefits of seafood consumption. GLOBEFISH Research Programme, Vol. 108, Rome, FAO 2013, p.28. Good report.

MAF. (2011). Investment Guidelines for Aquaculture Development in the Sultanate of Oman. Ministry of Agriculture and Fisheries Wealth with assistance commissioned from Curtis, Mallet-Prevost, Muscat.

MAF. (2012). Annual Report for the Minsitry of Agriculture and Fisheries Wealth. Ministry of Agriculture and Fisheries Wealth, Muscat, Sultanate of Oman.

Mbaga, M. D., Al-Jufaily, S. M., \& Al Belushi, M. M. S. (2012). The Potential Economic Loss to the Oman Economy as a Result of Exporting Unprocessed Fish. Journal of Food Products Marketing, 18(3), 186-199.

Ministerial Decision. (2009). Fishery Quality Control Regulation 12/2009. Ministry of Agriculture and Fisheries Wealth, Muscat, Sultanate of Oman.

MNE. (2007a). Long-term development strategy (1996-2020): Vision for Oman's Economy (Oman 2020). Ministry of National Economy, Sultanate of Oman.

MNE. (2007b). Seventh Five-Year Development Plan 2006-2010. Ministry of National Economy, Sultanate of Oman.

NCSI. (2013). National Statistical Year Book. Center for Statistical and Information, Sultanate of Oman.

Omezzine, A. (1998). On-shore fresh fish markets in Oman: . A descriptive analysis. Agribusiness International, 10(1).

Omezzine, A., Al-Oufi, H., \& Al-Akhzami, Y. (2004). The marketing system of fresh fish products on Masirah island in the Sultanate of Oman: a comprehensive reassessment. Marine Resource Economics 19,407-416.

Omezzine, A., Zaibet, L., Al-Oufi, H.,. (1996). The marketing system of fresh fish products on the Masirah Island in the Sultanate of Oman. . Mar. Resour. Econ. 11, 203-210. 
Opara Linus U. and Al-Jufaili Saud M. (2006). Status of Fisheries Postharvest Industry in the Sultanate of Oman: Part 2-Quantification of Fresh Fish Losses. Journal of Fisheries International, 1(2), 150-156.

Poulose Yesudhason, Moza Al-Busaidi, Waleed AK Al-Rahbi, Aaliah S Al-Waili, Adel K Al-Nakhaili, AlMazrooei, N. A., \& Al-Habsi, S. H. (2013). Distribution patterns of toxic metals in the marine oyster Saccostrea cucullata from the Arabian Sea in Oman: spatial, temporal, and size variations. SpringerPlus, 2(282), 1-11.

Qatan, S. (2010). Evaluating the Governance System of Seafood Quality and Safety: A Survey-based Case Study of Seafood Industries in the Sultanate of Oman. (Master of Science), Sultan Qaboos University, Sultanate of Oman.

Qatan S. (2010). Operating a wholesale fish market in the sultanate of oman analyses of external factors. UNU-Fisheries Training Programme.

RECOFI. (2009). Third meeting of the Working Group on Fisheries Management: PROPOSAL BY THE SULTANATE OF OMAN IN RELATION TO THE DEVELOPMENT OF A RECOFI RECORD OF IUU FISHING VIOLATIONS. FAO; RECOFI :WGFM3/2009/5.

Regulation (EC) No 2073/2005. COMMISSION REGULATION (EC) No 2073/2005 of 15 November 2005 on microbiological criteria for foodstuffs. Official Journal of the European Union L 322/12 . L 338/1(22.12.2005).

Richlen, M. L., Morton, S. L., Jamali, E. A., Rajan, A., \& Anderson, D. M. (2010). The catastrophic 2008-2009 red tide in the Arabian gulf region, with observations on the identification and phylogeny of the fish-killing dinoflagellate Cochlodinium polykrikoides. Harmful Algae, 9(2), 163-172.

Royal Decree No. 26/2013. (2013). Agreement on Port State Measures to Prevent, Deter and Eliminate Illegal, Unreported and Unregulated Fishing.

Sudheesh, P. S., Al-Ghabshi, A., Al-Aboudi, N., Al-Gharabi, S., \& Al-Khadhuri, H. (2013). Evaluation of food contact surface contamination and the presence of pathogenic bacteria in seafood retail outlets in the Sultanate of Oman. Advance Journal of Food Science \& Technology, 5(2), 77-83.

Taylor, E. (2001). HACCP in small companies: benefit or burden? . Food Control, 12(217-222).

Thangaraja, M., Al-Aisry, A., \& Al-Kharusi, L. (2007). Harmful algal blooms and their impacts in the middle and outer ROPME sea area. Int. J. Ocean Oceanography, 2 (2007), 85-98.

Tolosa, I., de Mora, S. J., Fowler, S. W., Villeneuve, J.-P., Bartocci, J., \& Cattini, C. (2005). Aliphatic and aromatic hydrocarbons in marine biota and coastal sediments from the Gulf and the Gulf of Oman. Marine Pollution Bulletin, 50(12), 1619-1633.

USTR. (2014). Oman Free Trade Agreement. Retrieved Sept. 9, 2014, from <http://www.ustr.gov/trade-agreements/free-trade-agreements/oman-fta>

World Fish Center. (2005). Food safety standards and regulations: Implications for Asian fish exporters.

Worldfolio, T. (2012). Minister for Agriculture and Fisheries, about the future of the fishing business in Oman. Retrieved January, 2015, from <http://www.theworldfolio.com/interviews/fuadbin-jafar-bin-al-sajwani-minister-for-agriculture-and-fisheries-malaysia-n1016/1016/>

WTO. (2013). TRADE POLICY REVIEW REPORT BY OMAN. WT/TPR/G/295. from <http://www.wto.org/english/tratop e/tpr e/g295>

Zou, X. N., Lu, S. H., \& Liu, B. (1994). VOLATILE N-NITROSAMINES AND THEIR PRECURSORS IN CHINESE SALTED FISH - A POSSIBLE ETIOLOGIC FACTOR FOR NPC IN CHINA. International Journal of Cancer, 59(2), 155-158. 


\section{ACCEPTED MANUSCRIPT}

\section{List of figures and tables}

\section{List of Figures:}

- Figure 1. Seafood production from the artisanal and commercial fisheries from 1985 to 2013 (FSB., 2013)

- Figure 2. Primary routes for the distribution of fish and fishery products in Oman

- Figure 3. The status of the seafood establishments in Oman (number, percentage \%) Source: (FQCC, 2014)

- Figure 4. The evolution of Omani laws and regulations on seafood safety

- Figure 5. SWOT analysis of the Omani fishery sector

\section{List of tables:}

- Table 1. Fisheries exports and imports in quantity and values in 2013 


\begin{tabular}{lrrrrrr}
\hline & \multicolumn{3}{c}{ Exports } & \multicolumn{2}{c}{ Imports } \\
\cline { 2 - 7 } Quantities/Value & $\begin{array}{r}\text { Quantity } \\
\text { (Tonnes) }\end{array}$ & $\begin{array}{c}\text { Value } \\
\text { ('O00 USD) }\end{array}$ & $\begin{array}{c}\text { Unit price } \\
\text { (USD)/Tonnes }\end{array}$ & $\begin{array}{c}\text { Quantity } \\
\text { (Tonnes) }\end{array}$ & $\begin{array}{c}\text { Value ('000 } \\
\text { USD) }\end{array}$ & $\begin{array}{c}\text { Unit price } \\
\text { (USD)/Tonnes }\end{array}$ \\
\hline GCC Countries & 87597 & 153382 & 1751 & 4417 & 9984 & 2260 \\
European Union & 779 & 5582 & 7165 & 79 & 2995 & 37909 \\
North/South America & 1193 & 1956 & 1639 & 8 & 16 & 1948 \\
Asian Countries & 22446 & 56384 & 2512 & 2897 & 8065 & 2784 \\
Other Countries & 13674 & 34743 & 2541 & 4455 & 12795 & 2872 \\
\hline Total & $\mathbf{1 2 5 6 8 9}$ & $\mathbf{2 5 2 0 4 7}$ & $\mathbf{1 5 6 0 9}$ & $\mathbf{1 1 8 5 6}$ & $\mathbf{3 3 8 5 5}$ & $\mathbf{4 7 7 7 3}$ \\
\hline
\end{tabular}




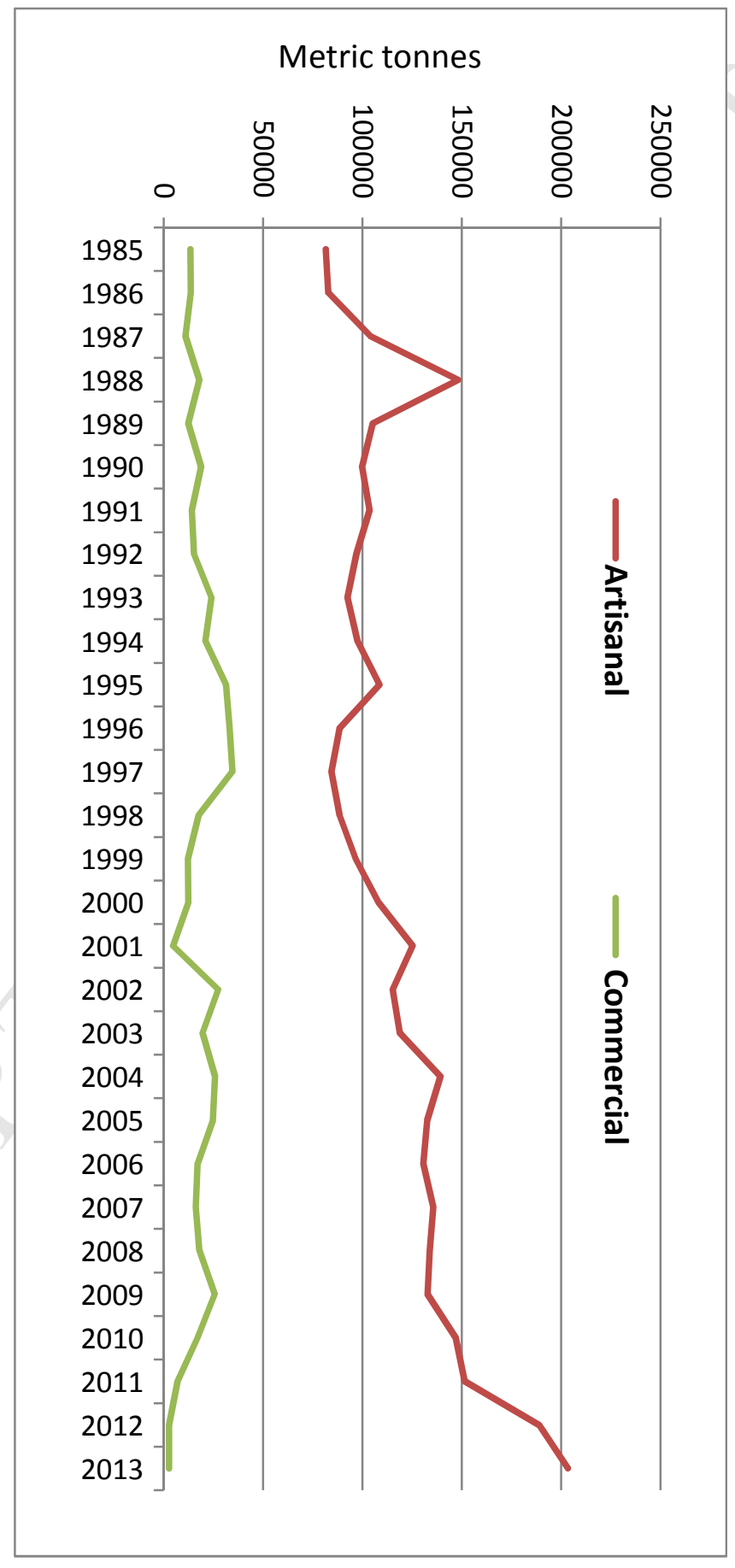




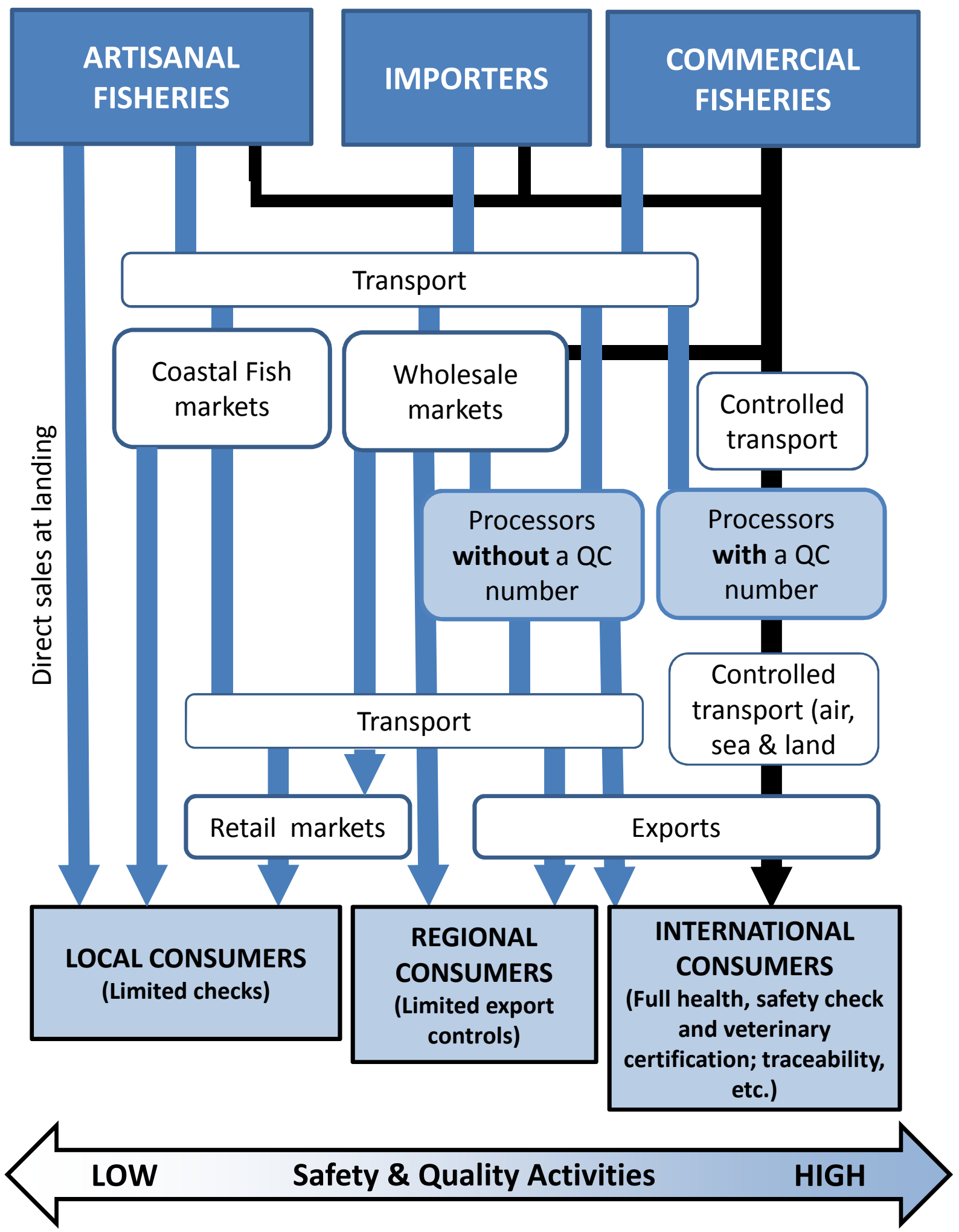




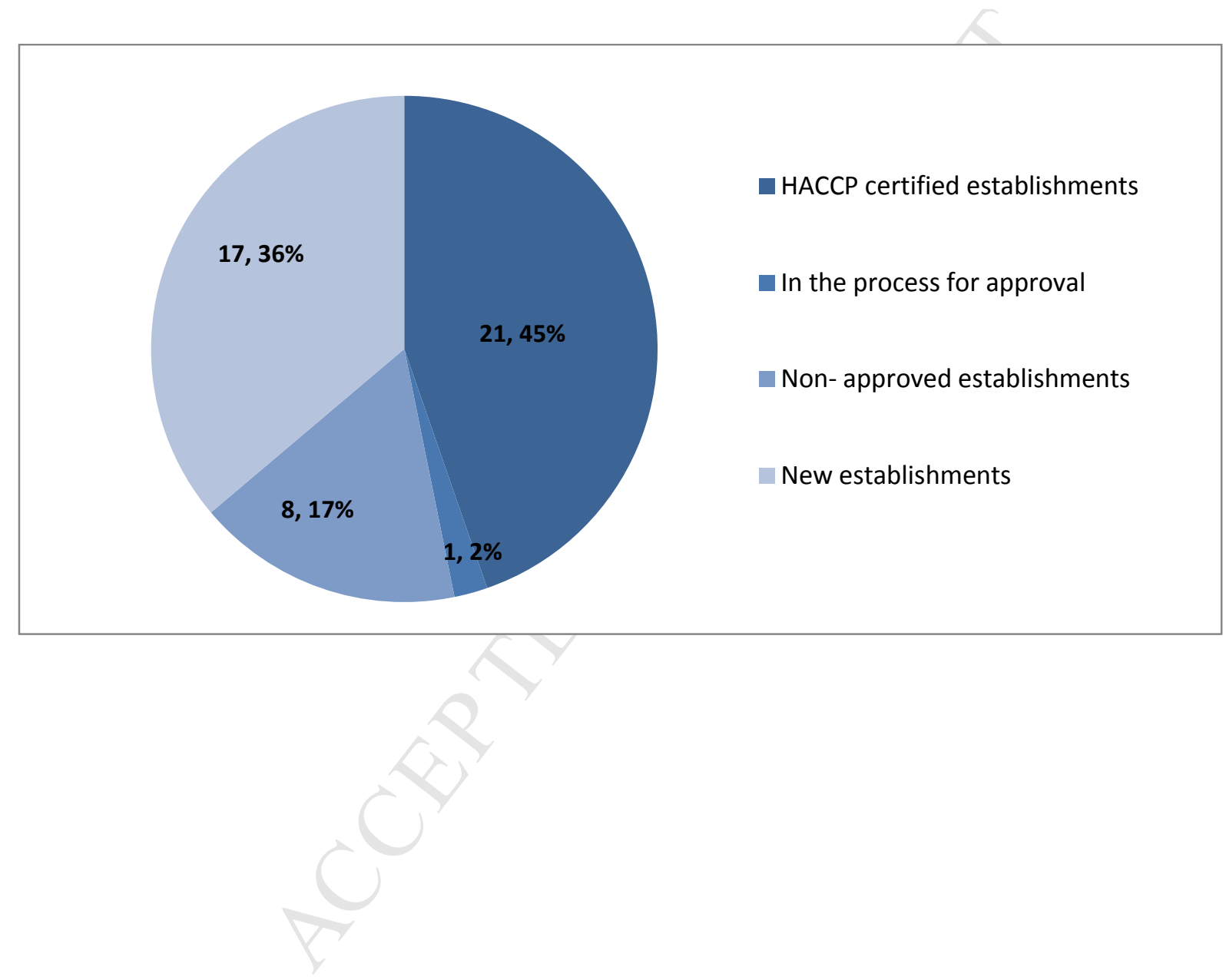


1994

1997

1998

2004

2009

\section{2}

2014
Executive Regulation for Marine Fishing and Protection of Living Aquatic Resources (MD No 3/82; RD No. 53/81)

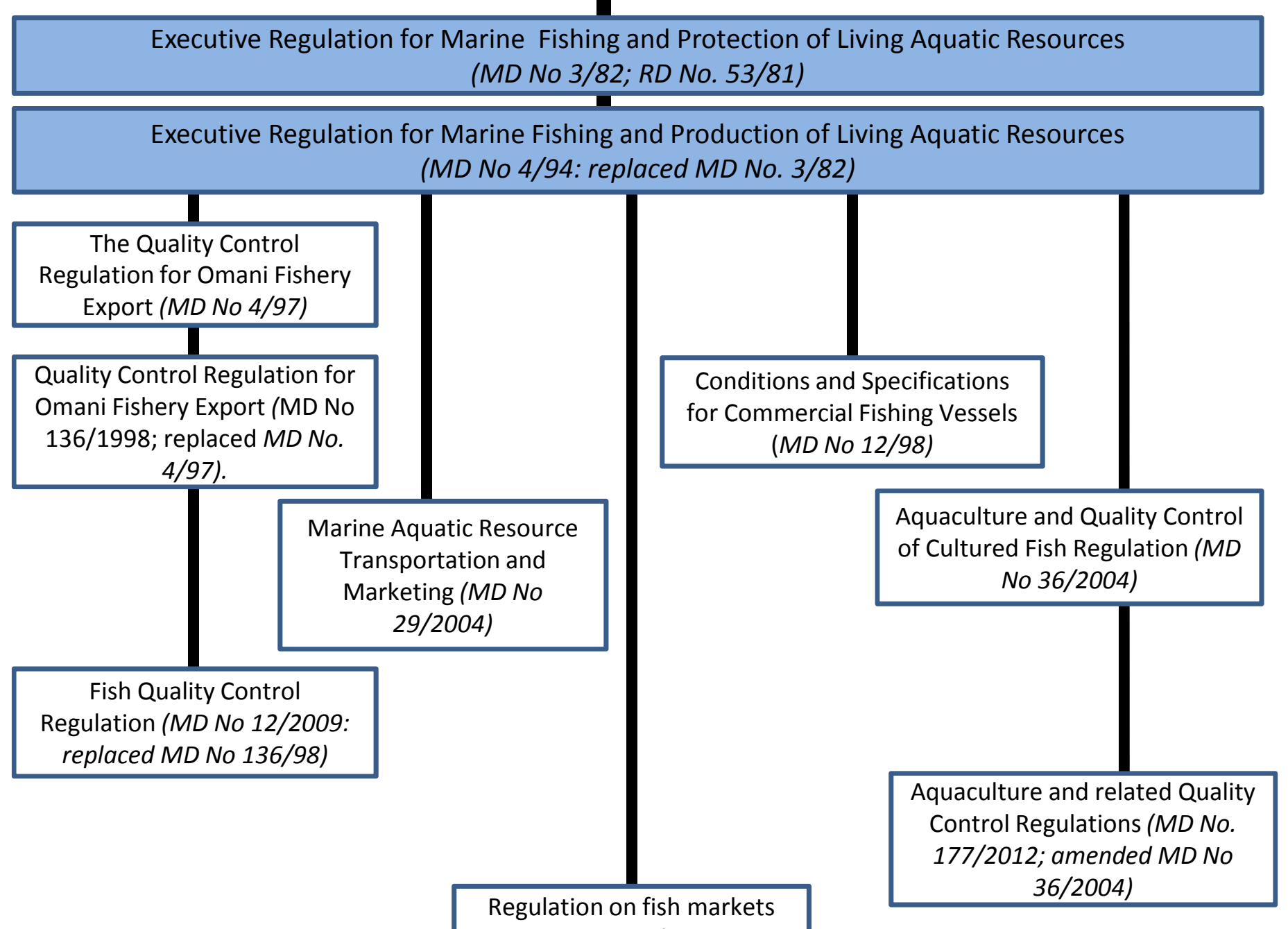
organization (MD No. 312/2014) 


\begin{tabular}{|c|c|}
\hline Strength & Weakness \\
\hline 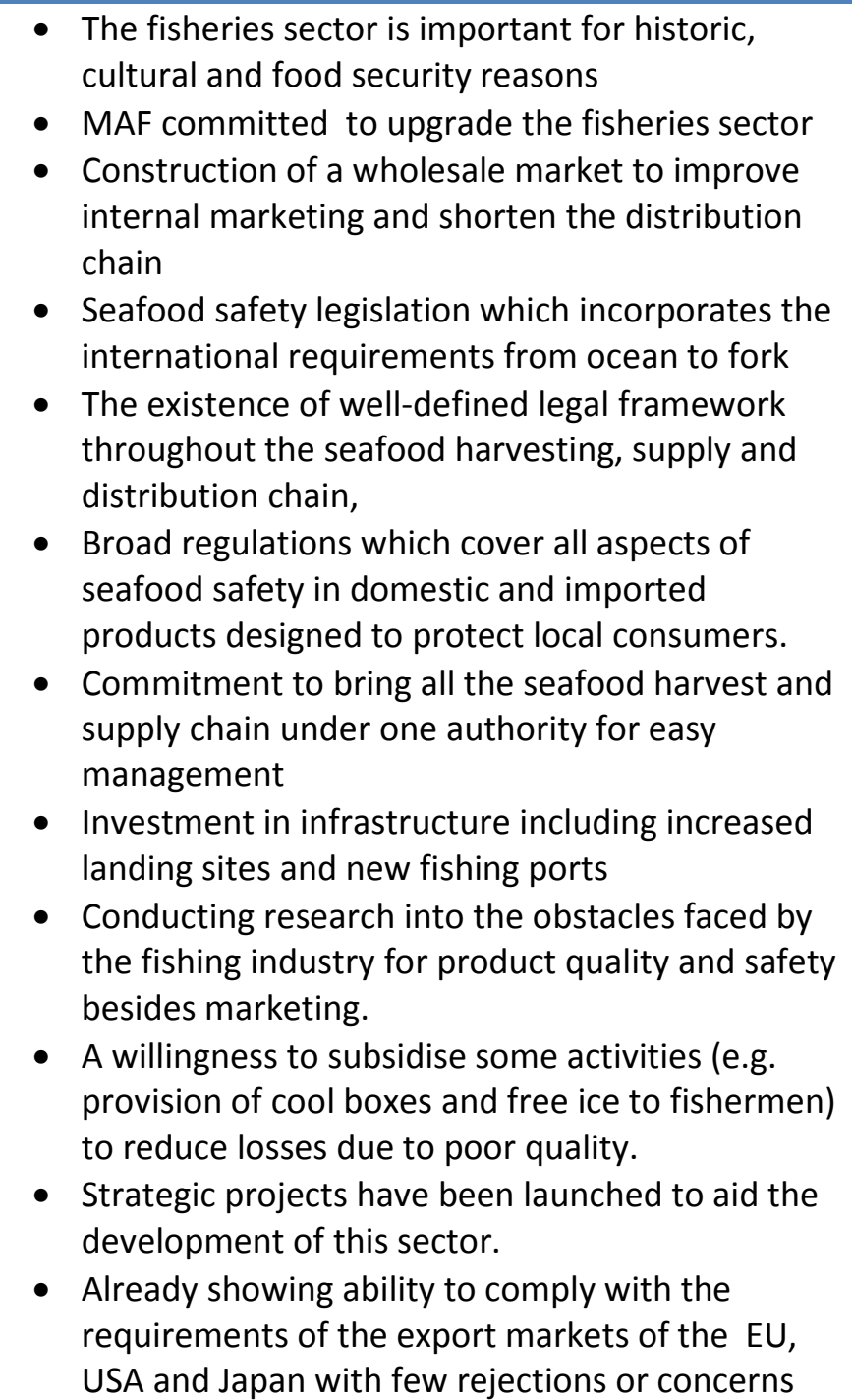 & $\begin{array}{l}\text { - The contribution of fisheries to economy is } \\
\text { - Vmall } \\
\text { - Pariable controls } \\
\text { goor infrastructure facilities in certain } \\
\text { - Strategic projects often lack continuity, have } \\
\text { weak implementation and have limited long } \\
\text { term impact } \\
\text { - Implementing international safety } \\
\text { requirements is a burden on small and medium } \\
\text { scale industries that serve the local markets. } \\
\text { - Lack of public health data (e.g. food poisoning } \\
\text { cases) makes it difficult to assess the benefit of } \\
\text { enhanced controls } \\
\text { - Despite over } 16 \text { years of trying, only } 21 \text { out of } \\
43 \text { establishments have managed to } \\
\text { implement food safety management systems } \\
\text { such as HACCP } \\
\text { - Lack of skilled manpower and resources to } \\
\text { meet demands of international standards and } \\
\text { requirements }\end{array}$ \\
\hline
\end{tabular}

\begin{tabular}{|c|c|}
\hline Opportunities & Threats \\
\hline $\begin{array}{l}\text { - Potential to significantly increase exports for both } \\
\text { the high value markets and other regional } \\
\text { markets } \\
\text { - Strategic location with potential to become a } \\
\text { regional hub for trade in wild and cultured } \\
\text { fisheries } \\
\text { - Potential for aquaculture development }\end{array}$ & $\begin{array}{l}\text { - Possible reduction in political commitment with } \\
\text { reduced government money for investment } \\
\text { - Competition from other countries leading to } \\
\text { loss of international market share } \\
\text { - Continued growth of exports to other GCC } \\
\text { countries leading to a reduction in available } \\
\text { supplies for potential export to high value } \\
\text { markets } \\
\text { - Increased problems caused by environmental } \\
\text { issues (e.g. algal blooms or high cadmium } \\
\text { levels) } \\
\text { - Increased exports of fish could hamper the } \\
\text { development of local processors capable of } \\
\text { developing and exporting added value products }\end{array}$ \\
\hline
\end{tabular}




\section{Highlights:}

- Seafood safety and controls in Oman are reviewed

- The complex supply chain in Oman for seafood is described

- Control requirements are identified and vary according to the final market

- Improvements have occurred but the research indicates that further progress is needed 